\title{
Front Matter: Volume 8732
}

, "Front Matter: Volume 8732," Proc. SPIE 8732, Atmospheric Propagation X, 873201 (22 May 2013); doi: 10.1117/12.2030327

SPIE Event: SPIE Defense, Security, and Sensing, 2013, Baltimore, Maryland, SPIE. United States 


\title{
PROCEEDINGS OF SPIE
}

\section{Atmospheric Propagation X}

\author{
Linda M. Wasiczko Thomas \\ Earl J. Spillar \\ Editors
}

30 April-1 May 2013

Baltimore, Maryland, United States

Sponsored and Published by

SPIE

Volume 8732 
The papers included in this volume were part of the technical conference cited on the cover and title page. Papers were selected and subject to review by the editors and conference program committee. Some conference presentations may not be available for publication. The papers published in these proceedings reflect the work and thoughts of the authors and are published herein as submitted. The publisher is not responsible for the validity of the information or for any outcomes resulting from reliance thereon.

Please use the following format to cite material from this book:

Author(s), "Title of Paper," in Atmospheric Propagation X, edited by Linda M. Wasiczko Thomas, Earl J. Spillar, Proceedings of SPIE Vol. 8732 (SPIE, Bellingham, WA, 2013) Article CID Number.

ISSN: 0277-786X

ISBN: 9780819495235

Published by

SPIE

P.O. Box 10, Bellingham, Washington 98227-0010 USA

Telephone +1 3606763290 (Pacific Time) · Fax +1 3606471445

SPIE.org

Copyright (C) 2013, Society of Photo-Optical Instrumentation Engineers.

Copying of material in this book for internal or personal use, or for the internal or personal use of specific clients, beyond the fair use provisions granted by the U.S. Copyright Law is authorized by SPIE subject to payment of copying fees. The Transactional Reporting Service base fee for this volume is $\$ 18.00$ per article (or portion thereof), which should be paid directly to the Copyright Clearance Center (CCC), 222 Rosewood Drive, Danvers, MA 01923. Payment may also be made electronically through CCC Online at copyright.com. Other copying for republication, resale, advertising or promotion, or any form of systematic or multiple reproduction of any material in this book is prohibited except with permission in writing from the publisher. The CCC fee code is $0277-786 \mathrm{X} / 13 / \$ 18.00$.

Printed in the United States of America.

Publication of record for individual papers is online in the SPIE Digital Library.

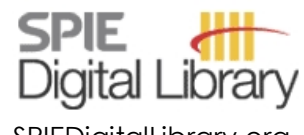

SPIEDigitalLibrary.org

Paper Numbering: Proceedings of SPIE follow an e-First publication model, with papers published first online and then in print and on CD-ROM. Papers are published as they are submitted and meet publication criteria. A unique, consistent, permanent citation identifier (CID) number is assigned to each article at the time of the first publication. Utilization of CIDs allows articles to be fully citable as soon as they are published online, and connects the same identifier to all online, print, and electronic versions of the publication. SPIE uses a six-digit CID article numbering system in which:

- The first four digits correspond to the SPIE volume number.

- The last two digits indicate publication order within the volume using a Base 36 numbering

system employing both numerals and letters. These two-number sets start with 00, 01, 02, 03, 04,

$05,06,07,08,09,0 A, 0 B \ldots$. OZ, followed by 10-1Z, 20-2Z, etc.

The CID Number appears on each page of the manuscript. The complete citation is used on the first page, and an abbreviated version on subsequent pages. Numbers in the index correspond to the last two digits of the six-digit CID Number. 


\title{
Contents
}

\author{
$\checkmark \quad$ Conference Committee
}

\section{SESSION 1 MEASUREMENTS AND SYSTEMS}

873202 Atmospheric transmission from an instrument measuring scatter at $1550 \mathrm{~nm}$ [8732-7] M. J. Vilcheck, C. I. Moore, R. Mahon, J. Murphy, A. Bucholtz, H. R. Burris, L. M. Thomas, W. Rabinovich, U. S. Naval Research Lab. (United States)

873204 Multi-wavelength operation of a control algorithm for mobile FSO node alignment [8732-10] D. Zhou, Univ. of Oklahoma-Tulsa (United States); P. G. LoPresti, Univ. of Tulsa (United States); H. Refai, Univ. of Oklahoma-Tulsa (United States)

\section{SESSION 2 MODELING OF THE CHANNEL}

873205 Cloud-free line-of-sight estimation for free space optical communications (Invited Paper) [8732-1]

R. A. Venkat, D. W. Young, Johns Hopkins Applied Physics Lab. (United States)

873206 Simulation of stochastic signals for FSO communication systems through spectral representation [8732-4]

J. P. G. de Oliveira, Univ. of Pernambuco (Brazil) and FITec - Fundacao para Inovacoes Tecnologicas (Brazil)

873207 Strehl ratio simulation results under strong turbulence conditions for actively compensated free-space optical communication systems [8732-5]

J. C. Juarez, D. M. Brown, D. W. Young, Johns Hopkins Univ. Applied Physics Lab. (United States)

873208 Sparse spectrum model for the turbulent phase simulations [8732-3]

M. Charnotskii, Zel Technologies, LLC (United States) and National Oceanic and Atmospheric Administration (United States)

\section{SESSION 3 EXPERIMENTAL ANALYSIS}

$87320 \mathrm{~A}$ Buffer requirements of an optical communication system in atmospheric turbulence [8732-11]

T. T. Leclerc, R. L. Phillips, L. C. Andrews, R. Crabbs, Univ. of Central Florida (United States)

8732 OB Propagation statistical analysis for SMF-coupled free-space optical signal under weak to medium atmospheric turbulences [8732-12]

Y. Arimoto, National Institute of Information and Communications Technology (Japan) 
$87320 \mathrm{C}$ Wavelength diversity assessment of fiber bundle receiver under misalignment and turbulence [8732-14]

P. G. LoPresti, W. Yi, E. Rohlman, Univ. of Tulsa (United States); H. Refai, Univ. of OklahomaTulsa (United States)

\section{SESSION 4 HIGH ENERGY AND BEAM CONTROL ANALYSIS}

8732 OD A nonlinear OPC technique for laser beam control in turbulent atmosphere [8732-17] V. Markov, A. Khizhnyak, Advanced Systems \& Technologies, Inc. (United States); P. Sprangle, U. S. Naval Research Lab. (United States) and Univ. of Maryland, College Park (United States); A. Ting, U. S. Naval Research Lab. (United States); L. DeSandre, Office of Naval Research (United States); B. Hafizi, U. S. Naval Research Lab. (United States)

$87320 \mathrm{G}$ Scattering from a rough surface in presence of atmospheric turbulence [8732-16] S. Basu, Air Force Institute of Technology (United States) and Oak Ridge Institute for Science and Education (United States); M. W. Hyde, Air Force Institute of Technology (United States); J. E. McCrae, Air Force Institute of Technology (United States) and Oak Ridge Institute for Science and Education (United States); S. T. Fiorino, Air Force Institute of Technology (United States)

$8732 \mathrm{OH}$ PITBUL: a physics-based modeling package for imaging and tracking of airborne targets for HEL applications including active illumination [8732-18] N. R. Van Zandt, Air Force Institute of Technology (United States); J. E. McCrae, Air Force Institute of Technology (United States) and Oak Ridge Institute for Science and Education (United States); S. T. Fiorino, Air Force Institute of Technology (United States)

Author Index 


\title{
Conference Committee
}

\author{
Symposium Chair
}

Kenneth R. Israel, Major General (USAF Retired) (United States)

Symposium Cochair

David A. Whelan, Boeing Defense, Space, and Security

(United States)

Conference Chairs

Linda M. Wasiczko Thomas, U.S. Naval Research Laboratory (United States)

Earl J. Spillar, Air Force Research Laboratory (United States)

Conference Program Committee

Ammar Al-Habash, Raytheon Space \& Airborne Systems (United States)

Gary Baker, Lockheed Martin Space Systems Company (United States)

Harris R. Burris Jr., U.S. Naval Research Laboratory (United States)

Gary G. Gimmestad, Georgia Tech Research Institute (United States)

Ken J. Grant, Defence Science and Technology Organisation (Australia)

Juan C. Juarez, Johns Hopkins University Applied Physics Laboratory (United States)

Christopher I. Moore, U.S. Naval Research Laboratory (United States)

William S. Rabinovich, U.S. Naval Research Laboratory (United States)

Jonathan M. Saint Clair, The Boeing Company (United States)

David H. Tofsted, U.S. Army Research Laboratory (United States)

Morio Toyoshima, National Institute of Information and Communications Technology (Japan)

Cynthia Y. Young, University of Central Florida (United States)

\section{Session Chairs}

1 Measurements and Systems

Juan C. Juarez, Johns Hopkins University Applied Physics Laboratory (United States)

2 Modeling of the Channel

Harris R. Burris Jr., U.S. Naval Research Laboratory (United States) 


\section{Experimental Analysis}

Linda M. Thomas, U.S. Naval Research Laboratory (United States)

4 High Energy and Beam Control Analysis

Ammar Al-Habash, Raytheon Space \& Airborne Systems

(United States) 